\title{
Attenuation of negative effects of saline stress in wheat plant by chitosan and calcium carbonate
}

\author{
Mervat Sh. Sadak ${ }^{*}$ (10) and Iman M. Talaat
}

\begin{abstract}
Background: Chitosan and $\mathrm{Ca}^{+}$are natural signal molecules that can be used in agriculture as biostimulants and elicitors. They enhance different physiological responses and mitigate the negative effects of salinity. So, this investigation was done to study the effect of soaking wheat grains in chitosan and $\mathrm{CaCO}_{3}(20$ and $40 \mathrm{mg} / \mathrm{L}$ ) on alleviating the adverse effect of salinity stress $(0.0$ and $5000 \mathrm{mg} / \mathrm{L})$ on growth, some biochemical and physiological and yields of wheat plant.
\end{abstract}

Results: Shoot length (cm), leaves no/tiller, shoot dry weight (g), root fresh weight (g) and root dry weight (g) were significantly decreased as a result of salt stress. Soaking wheat grains in Chitosan or $\mathrm{CaCO}_{3}$ significantly promoted plant growth under normal and stressed conditions. Irrigation of wheat plants with saline water significantly decreased photosynthetic pigments (Chlo- $a$, Chlo-b, carotenoids and total pigments) in addition to Chlo-a/Chlo-b ratio, indole acetic acid content in the plant leaves. Meanwhile, saline water significantly increased phenolics, total soluble sugars (TSS) and proline content. $\mathrm{H}_{2} \mathrm{O}_{2}$ and lipid peroxidation expressed by malondialdehyde (MDA) content clearly showed significant increases under salinity stress compared with untreated control. Soaking wheat grains in chitosan or $\mathrm{CaCO}_{3}$ before sawing significantly increased the accumulation of $\mathrm{H}_{2} \mathrm{O}_{2}$ and MDA in the leaves of wheat plants. Treatment of wheat grains with chitosan or $\mathrm{CaCO}_{3}$ significantly promoted the activity of various antioxidant enzymes (SOD and POX) as compared to the control. CAT activity was significantly decreased as a result of chitosan or $\mathrm{CaCO}_{3}$ treatments. The highest CAT activity was recorded in plants irrigated with $5000 \mathrm{mg} / \mathrm{L}$ saline water followed by control plants which recoded 36.40 and $24.82 \mathrm{U} / \mathrm{min} / \mathrm{g} \mathrm{FW}$, respectively. On the other hand, irrigation of wheat plants with $5000 \mathrm{mg} / \mathrm{L}$ saline water significantly decreased spike length (cm), spikelets no/spike, grains wt/plant (g), 1000-grains wt (g), yield and biomass/plant (g) as well as, carbohydrate \% and protein \% compared with the control. However, treating wheat plants either with Chitosan or calcium carbonate resulted in obvious significant increases in carbohydrates and protein contents, especially in plants treated with $40 \mathrm{mg} / \mathrm{L}$ chitosan followed by $40 \mathrm{mg} / \mathrm{L}$ calcium carbonate. Soaking wheat grains in chitosan, especially at $40 \mathrm{mg} / \mathrm{L}$, exhibited the strongest scavenging potential (2,2-diphenyl-1-picryl-hydrazyl-hydrate assay (DPPH\%) followed by treatment with $40 \mathrm{mg} / \mathrm{L} \mathrm{CaCO}_{3}$.

Conclusion: In conclusion, the used treatment enhanced the protective parameters such as antioxidant enzymes, total phenols and free radical scavengers and consequently helped the plants to decrease lipid peroxidation, increased their tolerance and improved yield and spike quality. Application of $40 \mathrm{mg} / \mathrm{L}$ chitosan recorded the highest increment in the scavenging ability of the natural antioxidants of the plant extract toward the stable free radical $\mathrm{DPPH}$.

*Correspondence: mervat_sh24@yahoo.com

Botany Department, National Research Centre, 33 El Behouth Street,

Dokki, Giza 12622, Egypt 
Keywords: Ant-transpirants, Antioxidant enzymes, Chitosan, $\mathrm{CaCO}_{3}$, Growth, Salinity, Wheat, Yield

\section{Background}

Wheat plant (Triticum aestivum L.) is considered one of the most important crops. Salinity stress is a major limiting factor which negatively affects the growth and production of several crops all over the world. Salinity stress limits plant growth by adversely affecting various physiological and biochemical processes, such as photosynthesis, antioxidant phenomena, nitrogen metabolism, ion homeostasis and osmolyte accumulation (Ashraf 2004). Thus, salinity exerts its undesirable effects through osmotic inhibition and ionic toxicity and by disturbing the uptake and translocation of nutritional ions (Misra and Dwivedi 2004).

Chitosan is a natural biopolymer derived from chitin, a polysaccharide found in exoskeleton of crustaceans, insects as well as cell wall of fungi and some algae (Boonlertnirum et al. 2010). It is low toxic and inexpensive compound that is biodegradable and environmentally friendly with various applications in agriculture. Chitosan has been widely used in agricultural applications mainly for stimulation of plant immunity, to protect plants and food products against microorganisms (bacteria and fungi) (Hadwiger et al. 2002; ChunYan et al. 2003; Devlieghere et al. 2004; Patkowska et al. 2006; No et al. 2007). Also, many efforts were done to study the effect of chitosan on plant growth, development and productivity. A positive effect of chitosan was observed on the growth of roots, shoots and leaves of various plant species. Foliar application of chitosan increased growth and yield in sweet pepper, radish and sunflower (Ghoname et al. 2010; Farouk et al. 2011; Bakhoum et al. 2020). Similar results were also observed in grapevine and strawberry (Gornik et al. 2008; Abdel-Mawgoud et al. 2010). Recently, Sheikha and Al-Malki (2011) indicated that application of different concentrations of chitosan enhanced bean shoot and root length, fresh and dry weights of shoots, root and leaf area. In addition, foliar applications with chitosan resulted in higher vegetative growth and improvement in fruit quality of cucumber (Farouk et al. 2008). For other cultivated plants, Bittelli et al. (2001) reported that foliar application of chitosan decreased transpiration in pepper plants, and reduced water use by $26-43 \%$ while maintaining biomass production and yield.

Calcium is a universal signaling molecule and the calcium-sensing $(\mathrm{CaS})$ receptor is of fundamental importance for extracellular calcium signaling and calcium homeostasis (Bouschet et al. 2008). Calcium is an important second messenger in signal transduction pathways (Achary et al. 2013), mediating various defense responses to the action under environmental stresses (Pan et al. 2012). Calcium $\left(\mathrm{Ca}^{2+}\right)$ is micro and multifunctional element in plants used in different biochemical and physiological processes (Barker and Pilbeam 2007). Calcium is an essential nutrient for growth and development of plants which involved in various important functions as in stability of plant membrane and stabilization of cell wall as well as, increases a huge number of key enzymes activities and interacting with phytohormones (White and Broadley 2003). Moreover, it serves in the signaling network pathways as a secondary messenger under different abiotic stress (Sadak 2016). In addition, calcium appears to play a central role in many defense mechanisms which are induced by stress and calcium signaling is required for the acquisition of stress tolerance or resistance (Cousson 2009).

The aim of this study was to study the effect of chitosan and $\mathrm{Ca}^{2+}$ on growth, some physiological and biochemical aspects and yield of wheat plant irrigated with saline water.

\section{Methods}

\section{Experimental procedures}

Two pot experiments were conducted at the greenhouse of National Research Centre, Dokki, Cairo, Egypt, at the winter seasons of 2018/2019 and 2019/2020. Grains of wheat Sakha 94 were obtained from Agricultural Research Centre, Giza, Egypt. Chitosan and calcium carbonate used in the present work were supplied from Sigma-Aldrich. Wheat grains were soaked in different concentrations of Chitosan and $\mathrm{CaCO}_{3}(0.0,20$ and $40 \mathrm{mg} / \mathrm{L}$ ) for $12 \mathrm{~h}$ before sowing. The experimental design was complete randomized block design (CRBD) with 4 replicates. Grains of wheat were sown at November 25th; grains were selected for uniformity by choosing those of equal size and with the same color. Ten uniform air-dried wheat grains were sown along a central row in each pot at 30-mm depth in plastic pots, each filled with about $7 \mathrm{~kg}$ clay soil from Giza, consisting of the upper $10 \mathrm{~cm}$ of soil collected from an area of undisturbed native vegetation. To reduce compaction and improve drainage, the soil was mixed with yellow sand in a proportion of $3: 1(\mathrm{v} / \mathrm{v})$. Ten days after sowing, the seedlings were thinned to 5 seedlings per pot. Granular ammonium sulfate $20.5 \%$ $\mathrm{N}$ at a rate of $40 \mathrm{~kg} \mathrm{~N} \mathrm{ha}^{-1}$, and single superphosphate $\left(15 \% \mathrm{P}_{2} \mathrm{O}_{5}\right)$ at a rate of $60 \mathrm{~kg} \mathrm{P}_{2} \mathrm{O}_{5} \mathrm{ha}^{-1}$ were added to each pot. The $\mathrm{N}$ and $\mathrm{P}$ fertilizers were mixed thoroughly into soil of each pot immediately before sowing. Soil field capacity in the pots was estimated by saturating the soil 
in the pots with water and weighing them after they had drained for $48 \mathrm{~h}$. Field water capacity was 0.36 . The two saline water levels used were $0.0,5000 \mathrm{mg} / \mathrm{L}$, respectively. The preparation of salt mixture according to Stroganov (1962) equation is shown in Table 1. The pots were irrigated with equal volumes of the various salinity levels.

The component of specific anions and cations in chloride mixture is expressed as percentage of total mill equivalents.

Plant samples were taken after 75 days from sowing for measurements of growth characters as shoot length $(\mathrm{cm})$, leaves no/tiller, shoot, root fresh and dry weight (g/plant). Plant samples were taken for chemical analysis as photosynthetic pigments, indole acetic acid (IAA $\mu \mathrm{g} / 100 \mathrm{~g}$ fresh weight), hydrogen peroxide $\left(\mathrm{H}_{2} \mathrm{O}_{2}, \mu \mathrm{g} / 100 \mathrm{~g}\right.$ fresh weight), lipid peroxidation (MDA, $\mu \mathrm{g} / 100 \mathrm{~g}$ fresh weight) contents and some antioxidant enzymes as super oxide dismutase (SOD), peroxidase (POX) and catalase (CAT) (U/min/g fresh $\mathrm{wt}$ ). After drying of plant samples, total soluble sugars (TSS, mg/g dry weight) proline $(\mathrm{mg} / 100 \mathrm{~g}$ dry wt) were determined. At harvest: spike length $(\mathrm{cm})$, spike weight (g), spikelet's number/spike, grains number/spike, grains weight/plant (g), 1000-grains weight (g) and biomass yield/plant (g). Some nutritional values of the yielded grains were determined as carbohydrate\%, protein\%, phenolics (mg/100 g dry weight), flavonoids (mg/100 g dry weight) and DPPH\%.

\section{Measurements}

Photosynthetic pigments: Chlorophyll $a$, chlorophyll $b$ and carotenoids were determined using spectrophotometric method described by Lichtenthaler and Buschmann (2001). Indole acetic acid content was extracted and analyzed by the method of Larsen et al. (1962). Total soluble sugars (TSS) were extracted by the method of (Homme et al. 1992). TSS were analyzed according to (Yemm and Willis 1954). Proline was extracted and assayed according to the method described by Bates et al. (1973). The level of lipid peroxidation was measured by determining the levels of malondialdehyde (MDA) content using the method of Hodges et al. (1999). Hydrogen peroxide content was determined using the method of Velikova et al. (2000). Enzyme extracts were collected following the method described by Chen and
Wang (2006). Superoxide dismutase (SOD, EC 1.12.1.1) activity was spectrophotometrically assayed at $560 \mathrm{~nm}$ by nitro-blue-tetrazolium (NBT) reduction method (Chen and Wang 2006). Peroxidase (POX, EC 1.11.1.7) activity assayed according to the method of Bergmeyer (1974). Catalase (CAT) (EC 1.11.1.6) activity was determined spectrophotometrically by following the decrease in absorbance at $240 \mathrm{~nm}$ (Chen and Wang 2006). The enzyme activities were calculated by Kong et al. (1999). Total carbohydrate determination was carried out according to Herbert et al. (1971). The protein content was determined by micro-Kjeldahl method according to A.O.A.C. (1990). Total phenol content was measured as described by Danil and George (1972). Flavonoid content of crude extract was determined by the aluminum chloride colorimetric method (Chang et al. 2002). The free radical scavenging activity by grain extracts was done according to the method reported by Gyamfi et al. (2002).

\section{Statistical analysis}

The data were statistically analyzed on complete randomized design system (CRBD) with four replicates. Combined analysis of the two growing seasons was carried out. Means were compared by using least significant difference (LSD) at 5\% levels of probability (Snedecor and Cochran 1980).

\section{Results}

Data presented in Table 2 indicated that irrigation of wheat plants with $5000 \mathrm{mg} / \mathrm{L}$ saline water markedly decreased plant growth parameters (shoot length, leaves number per tiller, shoot fresh and dry weights, and root fresh and dry weights). Meanwhile, soaking wheat grains in chitosan or calcium carbonate (either at 20 or $40 \mathrm{mg} / \mathrm{L}$ ) before sowing significantly promoted all the above-mentioned growth criteria, especially in plants treated with $40 \mathrm{mg} / \mathrm{L}$ chitosan, followed by plants treated with $\mathrm{CaCO}_{3}$.

Data presented in Table 3 indicated that irrigation of wheat plants with $5000 \mathrm{mg} / \mathrm{L}$ saline water significantly decreased yield and yield components under study (i.e., spike length $(\mathrm{cm})$, spike weight $(\mathrm{g})$, spikelet's number/ spike, grains number/spike, grains weight/plant, 1000 grains weight, yield and biomass/ plant (g)). On the

Table 1 The components of the salt mixture used for chloride salinization expressed as \% of the total salt content

\begin{tabular}{lllllll}
\hline $\mathbf{M g S O}_{4}$ & & $\mathrm{CaSO}_{4}$ & $\mathrm{NaCl}$ & $\mathbf{M g C l}_{2}$ & $\mathrm{CaCO}_{3}$ \\
\hline 10 & 1 & & 78 & 2 & 9 \\
\hline $\mathrm{Na}^{+}$ & $\mathbf{M g}^{+2}$ & $\mathbf{C a}^{+2}$ & & $\mathbf{S O}^{-2}$ & $\mathbf{C l}^{-}$ & $\mathbf{C O}^{-2}$ \\
\hline 38 & 6 & 6 & 5 & 40 & 5 \\
\hline
\end{tabular}


Table 2 Effect of chitosan and calcium carbonate $(0,20$ and $40 \mathrm{mg} / \mathrm{L})$ on morphological characters of wheat plant grown under different salinity levels $(0,5000 \mathrm{mg} / \mathrm{L})$

\begin{tabular}{|c|c|c|c|c|c|c|}
\hline Treatments & $\begin{array}{l}\text { Shoot length } \\
(\mathrm{cm})\end{array}$ & Leaves no/tiller & $\begin{array}{l}\text { Shoot fresh wt } \\
\text { (g) }\end{array}$ & $\begin{array}{l}\text { Shoot dry wt } \\
\text { (g) }\end{array}$ & $\begin{array}{l}\text { Root fresh wt } \\
\text { (g) }\end{array}$ & $\begin{array}{l}\text { Root dry } \\
\text { weight (g) }\end{array}$ \\
\hline Control & 32.00 & 4.33 & 1.90 & 0.61 & 0.41 & 0.10 \\
\hline \multicolumn{7}{|l|}{$0 \mathrm{mg} / \mathrm{L}$ saline water } \\
\hline $20 \mathrm{mg} / \mathrm{L}$ chitosan & 34.00 & 5.00 & 2.31 & 0.76 & 0.58 & 0.12 \\
\hline $40 \mathrm{mg} / \mathrm{L}$ chitosan & 36.00 & 6.00 & 2.79 & 0.94 & 0.70 & 0.14 \\
\hline $20 \mathrm{mg} / \mathrm{L} \mathrm{CaCO}_{3}$ & 34.33 & 5.33 & 2.25 & 0.72 & 0.57 & 0.11 \\
\hline $40 \mathrm{mg} / \mathrm{L} \mathrm{CaCO}_{3}$ & 38.67 & 6.00 & 2.43 & 0.90 & 0.63 & 0.14 \\
\hline 5000 mg/l saline water & 29.67 & 3.67 & 1.44 & 0.54 & 0.36 & 0.07 \\
\hline \multicolumn{7}{|l|}{5000 mg/L saline water } \\
\hline $20 \mathrm{mg} / \mathrm{L}$ chitosan & 32.00 & 4.33 & 1.62 & 0.65 & 0.43 & 0.09 \\
\hline $40 \mathrm{mg} / \mathrm{L}$ chitosan & 34.00 & 5.00 & 2.04 & 0.73 & 0.43 & 0.10 \\
\hline $20 \mathrm{mg} / \mathrm{L} \mathrm{CaCO}_{3}$ & 33.00 & 4.33 & 1.53 & 0.56 & 0.37 & 0.09 \\
\hline $40 \mathrm{mg} / \mathrm{L} \mathrm{CaCO}_{3}$ & 33.67 & 4.67 & 1.81 & 0.65 & 0.42 & 0.10 \\
\hline $\operatorname{LSD}(5 \%)$ & 2.70 & 0.81 & 0.21 & 0.07 & 0.06 & 0.01 \\
\hline
\end{tabular}

Data are means of two seasons

Table 3 Effect of chitosan and calcium carbonate $(0,20$ and $40 \mathrm{mg} / \mathrm{L})$ on yield and its components of wheat plant grown under different salinity levels $(0,5000 \mathrm{mg} / \mathrm{L})$

\begin{tabular}{|c|c|c|c|c|c|c|c|}
\hline Treatments & $\begin{array}{l}\text { Spike length } \\
\text { (cm) }\end{array}$ & Spike wt (g) & $\begin{array}{l}\text { Spikelets no/ } \\
\text { spike }\end{array}$ & Grains no/spike & $\begin{array}{l}\text { Grains wt/ } \\
\text { plant (g) }\end{array}$ & $\begin{array}{l}1000 \text { grains } \\
\text { wt (g) }\end{array}$ & $\begin{array}{l}\text { Biomass/ } \\
\text { plant (g) }\end{array}$ \\
\hline Control & 9.50 & 1.13 & 13.33 & 30.20 & 2.11 & 30.21 & 3.52 \\
\hline \multicolumn{8}{|l|}{$0 \mathrm{mg} / \mathrm{L}$ saline water } \\
\hline 20 mg/L chitosan & 10.77 & 1.28 & 14.67 & 42.73 & 2.31 & 61.00 & 3.79 \\
\hline 40 mg/L chitosan & 11.90 & 1.40 & 16.00 & 46.73 & 2.87 & 66.67 & 3.87 \\
\hline $20 \mathrm{mg} / \mathrm{L} \mathrm{CaCO}_{3}$ & 10.33 & 1.21 & 14.33 & 42.20 & 2.30 & 60.67 & 3.72 \\
\hline $40 \mathrm{mg} / \mathrm{L} \mathrm{CaCO}_{3}$ & 11.73 & 1.33 & 15.33 & 44.33 & 2.33 & 63.67 & 3.81 \\
\hline 5000 mg/l saline water & 8.00 & 1.06 & 9.00 & 25.41 & 1.82 & 25.41 & 3.08 \\
\hline \multicolumn{8}{|l|}{5000 mg/L saline water } \\
\hline $20 \mathrm{mg} / \mathrm{L}$ chitosan & 9.33 & 1.16 & 10.33 & 28.05 & 1.95 & 55.67 & 3.35 \\
\hline $40 \mathrm{mg} / \mathrm{L}$ chitosan & 10.33 & 1.21 & 11.67 & 31.99 & 2.12 & 59.00 & 3.56 \\
\hline $20 \mathrm{mg} / \mathrm{L} \mathrm{CaCO}_{3}$ & 8.33 & 1.09 & 10.00 & 28.15 & 1.92 & 52.33 & 3.18 \\
\hline $40 \mathrm{mg} / \mathrm{L} \mathrm{CaCO}_{3}$ & 9.00 & 1.15 & 10.33 & 34.47 & 1.93 & 54.67 & 3.29 \\
\hline $\operatorname{LSD}(5 \%)$ & 0.62 & 0.05 & 0.92 & 1.74 & 0.05 & 0.69 & 0.06 \\
\hline
\end{tabular}

Data are means of two seasons

other hand, exogenous treatment of chitosan and $\mathrm{CaCO}_{3}$ increased significantly yield and its components of wheat plants grown either under normal irrigation water or salinity stress conditions as compared with their corresponding untreated controls. Meanwhile, treating plants with $\mathrm{CaCO}_{3}$ resulted in similar results, but to a lesser degree (Table 3). $40 \mathrm{mg} / \mathrm{L}$ chitosan and $40 \mathrm{mg} / \mathrm{L} \mathrm{CaCO}_{3}$ treatments were more effective than $20 \mathrm{mg} / \mathrm{L}$ of either chitosan or $\mathrm{CaCO} 3$ treatments.

It is obvious that irrigation of wheat plants with saline water significantly decreased photosynthetic pigments (chlorophyll- $a$, chlorophyll- $b$, carotenoids and total pigments) in addition to chlorophyll- $a$ /chlorophyll- $b$ ratio and endogenous indole acetic acid contents in the plant leaves (Table 4). On the other hand, soaking wheat grains in chitosan at $40 \mathrm{mg} / \mathrm{L}$ significantly increased chlorophyll-a content followed by treating grains with $40 \mathrm{mg} / \mathrm{L}$ $\mathrm{CaCO}_{3}$ (Table 4). Chlorophyll- $b$ and carotenoids contents as well as IAA contents followed the same trend. On the other hand, the ratio of chlorophyll- $a$ /chlorophyll- $b(a / b)$ was stable in all treatments irrigated with $5000 \mathrm{mg} / \mathrm{L}$ saline water. 
Table 4 Effect of chitosan and calcium carbonate $(0,20$ and $40 \mathrm{mg} / \mathrm{l})$ on photosynthetic pigments and IAA ( $\mu \mathrm{g} / 100 \mathrm{~g}$ fresh wt) of wheat plant growing under different salinity levels $(0,5000 \mathrm{mg} / \mathrm{l})$

\begin{tabular}{|c|c|c|c|c|c|c|}
\hline Treatments (mg/l) & Chlo-a & Chlo-b & Chlo-a/Chlo-b & Carotenoids & Total pigments & $\begin{array}{l}\text { IAA } \\
(\mu \mathrm{g} / 100 \mathrm{~g} \\
\text { fresh wt) }\end{array}$ \\
\hline Control & 12.44 & 7.52 & 1.65 & 2.50 & 22.46 & 26.97 \\
\hline \multicolumn{7}{|l|}{$0 \mathrm{mg} / \mathrm{L}$ saline water } \\
\hline 20 mg/L chitosan & 13.52 & 8.08 & 1.67 & 3.05 & 13.52 & 34.07 \\
\hline 40 mg/L chitosan & 14.57 & 8.60 & 1.69 & 3.75 & 14.60 & 44.07 \\
\hline $20 \mathrm{mg} / \mathrm{L} \mathrm{CaCO}_{3}$ & 13.36 & 7.96 & 1.68 & 2.64 & 13.23 & 31.53 \\
\hline $40 \mathrm{mg} / \mathrm{L} \mathrm{CaCO}_{3}$ & 13.89 & 8.27 & 1.68 & 3.38 & 13.83 & 40.04 \\
\hline 5000 mg/l saline water & 10.41 & 6.67 & 1.56 & 2.60 & 19.67 & 19.79 \\
\hline \multicolumn{7}{|l|}{5000 mg/L saline water } \\
\hline 20 mg/L chitosan & 11.71 & 7.20 & 1.63 & 3.33 & 13.20 & 25.16 \\
\hline 40 mg/L chitosan & 12.47 & 7.63 & 1.63 & 3.85 & 13.76 & 27.81 \\
\hline $20 \mathrm{mg} / \mathrm{L} \mathrm{CaCO}_{3}$ & 11.30 & 6.95 & 1.63 & 3.28 & 12.14 & 25.95 \\
\hline $40 \mathrm{mg} / \mathrm{L} \mathrm{CaCO}_{3}$ & 12.04 & 7.38 & 1.63 & 3.80 & 13.00 & 30.21 \\
\hline LSD (5\%) & 0.11 & 0.14 & 0.04 & 0.14 & 0.25 & 1.55 \\
\hline
\end{tabular}

Table 5 Effect of chitosan and calcium carbonate $(0,20$ and $40 \mathrm{mg} / \mathrm{L}$ ) on osmo-protectants (TSS mg/g fresh weight, proline $\mathrm{mg} / 100 \mathrm{~g}$ fresh weight and phenolics $\mathrm{mg} / 100 \mathrm{~g}$ dry weight) contents of wheat plant growing under different salinity levels $(0$, $5000 \mathrm{mg} / \mathrm{L})$

\begin{tabular}{|c|c|c|c|}
\hline Treatments & $\begin{array}{l}\text { TSS (mg/g } \\
\text { fresh wt) }\end{array}$ & $\begin{array}{l}\text { Proline } \\
\text { (mg/100 g } \\
\text { fresh wt) }\end{array}$ & $\begin{array}{l}\text { Phenolics } \\
\text { (mg/100 g dry } \\
\text { wt) }\end{array}$ \\
\hline Control & 11.37 & 33.05 & 27.07 \\
\hline \multicolumn{4}{|l|}{$0 \mathrm{mg} / \mathrm{L}$ saline water } \\
\hline 20 mg/L chitosan & 38.08 & 63.04 & 37.95 \\
\hline $40 \mathrm{mg} / \mathrm{L}$ chitosan & 43.74 & 68.70 & 30.12 \\
\hline $20 \mathrm{mg} / \mathrm{L} \mathrm{CaCO}_{3}$ & 36.48 & 61.49 & 47.15 \\
\hline $40 \mathrm{mg} / \mathrm{L} \mathrm{CaCO}_{3}$ & 41.29 & 65.64 & 56.60 \\
\hline 5000 mg/l saline water & 13.27 & 43.03 & 32.89 \\
\hline \multicolumn{4}{|l|}{5000 mg/L saline water } \\
\hline 20 mg/L chitosan & 47.73 & 72.58 & 38.91 \\
\hline 40 mg/L chitosan & 51.40 & 80.75 & 63.14 \\
\hline $20 \mathrm{mg} / \mathrm{L} \mathrm{CaCO}_{3}$ & 42.74 & 63.14 & 34.17 \\
\hline $40 \mathrm{mg} / \mathrm{L} \mathrm{CaCO}_{3}$ & 45.76 & 70.25 & 50.26 \\
\hline LSD (5\%) & 0.30 & 1.19 & 1.24 \\
\hline
\end{tabular}

Data presented in Table 5 indicated that irrigation of wheat plants with saline water significantly increased total soluble sugars (TSS) (mg/g fresh weight), proline content (mg/100 g dry weight) and phenolics $(\mathrm{mg} / 100 \mathrm{~g}$ dry wt). Moreover, treating wheat plants either with chitosan or calcium carbonate resulted in obvious significant increases in the above-mentioned parameters, especially in plants treated with $40 \mathrm{mg} / \mathrm{L}$ chitosan followed by $40 \mathrm{mg} / \mathrm{L}$ calcium carbonate (Table 5 ).
Data presented in Table 5 also indicated that soaking wheat grains in $20 \mathrm{mg} / \mathrm{L}$ chitosan or $\mathrm{CaCO}_{3}$ caused significant increases in phenolics content. Furthermore, soaking wheat grains in $40 \mathrm{mg} / \mathrm{L}$ chitosan or $\mathrm{CaCO}_{3}$ resulted in significant increases in total phenolics.

Lipid peroxidation expressed by malondialdehyde (MDA) content and $\mathrm{H}_{2} \mathrm{O}_{2}$ content clearly showed significant increases under salinity stress compared with control plants. Meanwhile, soaking wheat grains in chitosan or $\mathrm{CaCO}_{3}$ before sowing significantly decreased the accumulation of $\mathrm{H}_{2} \mathrm{O}_{2}$ and MDA in the leaves of wheat plants as compared with their corresponding untreated controls either at normal irrigated plants or saline treated plants as shown in Table 6.

Regarding to antioxidant enzymes, Table 6 clearly shows that irrigation of wheat plants with $5000 \mathrm{mg} / \mathrm{l}$ saline water caused significant increases in different enzymes superoxide dismutase SOD, peroxidase POX and catalase CAT as compared to those plants irrigated with tap water. Treatment of wheat grains with chitosan or $\mathrm{CaCO}_{3}$ significantly promoted the activity of various antioxidant enzymes (SOD and POX) as compared to the control (Table 6). On the other hand, CAT activity was significantly decreased as a result of chitosan or $\mathrm{CaCO}_{3}$ treatments. The highest CAT activity $(\mathrm{U} / \mathrm{min} / \mathrm{g} F W)$ was recorded in plants irrigated with $5000 \mathrm{mg} / \mathrm{l}$ saline water followed by control plants which recoded 36.40 and 24.82 $\mathrm{U} / \mathrm{min} / \mathrm{g} \mathrm{FW}$, respectively.

Data presented in Table 7 indicated that irrigation of wheat plants with saline water significantly decreased carbohydrate \% and protein \% compared with the control plants. Meanwhile, it increased significantly flavonoids 
Table 6 Effect of chitosan and calcium carbonate (0, 20 and $40 \mathrm{mg} / \mathrm{L}$ ) on $\mathrm{H}_{2} \mathrm{O}_{2}, \mathrm{MDA}(\mu \mathrm{g} / 100 \mathrm{~g}$ fresh $\mathrm{wt}$ ), and antioxidant enzymes (SOD, POX and CAT U/min/g FW) activities of wheat plant growing under different salinity levels $(0,5000 \mathrm{mg} / \mathrm{L})$

\begin{tabular}{lccccc}
\hline Treatments & $\mathbf{H}_{\mathbf{2}} \mathbf{O}_{\mathbf{2}}$ & MDA & SOD & POX & CAT \\
\hline Control & 4.46 & 7.76 & 28.53 & 62.99 & 24.82 \\
0 mg/L saline water & & & & & \\
20 mg/L chitosan & 4.14 & 7.43 & 32.68 & 66.59 & 11.72 \\
40 mg/L chitosan & 4.07 & 7.31 & 35.52 & 68.75 & 12.27 \\
20 mg/L CaCO & 4.24 & 7.62 & 31.45 & 65.54 & 11.69 \\
40 mg/L CaCO & 4.14 & 7.54 & 33.87 & 67.77 & 12.29 \\
5000 mg/l saline water & 6.38 & 10.95 & 31.75 & 65.97 & 36.40 \\
5000 mg/L saline water & & & & & \\
20 mg/L chitosan & 5.43 & 9.39 & 36.24 & 68.23 & 14.62 \\
40 mg/L chitosan & 5.04 & 8.11 & 37.90 & 72.30 & 15.55 \\
20 mg/L CaCO & 5.53 & 9.61 & 35.49 & 67.62 & 13.94 \\
40 mg/L CaCO & 4.90 & 8.68 & 36.85 & 69.55 & 14.85 \\
LSD (5\%) & 0.13 & 0.17 & 0.30 & 0.54 & 0.49 \\
\hline
\end{tabular}

content and DPPH activities of the yielded grains of wheat plant as compared with control plants. Treating wheat plants either with chitosan or calcium carbonate with different concentrations resulted in obvious significant increases in carbohydrates, protein content, flavonoids contents and DPPH activities especially in plants treated with $40 \mathrm{mg} / \mathrm{l}$ chitosan followed by $40 \mathrm{mg} / \mathrm{l} \mathrm{cal}-$ cium carbonate (Table 6). Data in Table 7 showed that salinity stress caused significant increases in the antioxidant activity (as DPPH radical scavenging capacity) of wheat grain. Also, foliar treatment of wheat plant with chitosan and $\mathrm{CaCO}_{3}$ with different concentrations (20 and $40 \mathrm{mMl}$ ) caused significant increases in the antioxidant activity as compared with control plants.

\section{Discussion}

Data presented in Tables 2 and 3 indicated that irrigation of wheat plants with $5000 \mathrm{mg} / \mathrm{l}$ saline water significantly decreased plant growth parameters and yield attributes. The obtained results of salinity stress are in agreement with those recorded by Abdel-Mawgoud et al. (2010), Sheikha and Al-Malki (2011) and Zehra et al. (2012), Rady et al. (2015) and Sadak (2016) on different plant species. In this concern, salinity stress limits plant growth and yield by adversely affecting various physiological and biochemical processes, such as photosynthesis, antioxidant phenomena, nitrogen metabolism, ion homeostasis and osmolyte accumulation (Ashraf 2004). Thus, salinity exerts its undesirable effects through osmotic inhibition and ionic toxicity and by disturbing the uptake and translocation of nutritional ions (Misra and Dwivedi 2004). Moreover, the reductions in yield and yield components of wheat plant under salinity stress might be through reductions in growth (Table 2) and photosynthetic pigments (Table 4) contents, thus reducing the output of photosynthesis (Anjum et al. 2003) and diminishing activities of Calvin cycle enzymes (Ashraf et al. 2013).

A positive effect of chitosan was observed on the growth and yield of various plant species. Foliar application of chitosan increased growth and yield in chilli and maize plants (Chookhongkha et al. 2012; Mondal et al. (2013). Similar results were also observed in grapevine and strawberry (Gornik et al. 2008; AbdelMawgoud et al. 2010). Sheikha and Al-Malki (2011) and Khan et al. (2018) indicated that application of different

Table 7 Effect of chitosan and calcium carbonate $(0,20$ and $40 \mathrm{mg} / \mathrm{L}$ ) on carbohydrates\%, protein\%, flavonoids (mg/100 g dry weight) contents and DPPH $\%$ of wheat plant grains growing under different salinity levels $(0,5000 \mathrm{mg} / \mathrm{L})$

\begin{tabular}{|c|c|c|c|c|}
\hline Treatments & Carbohydrate (\%) & Protein (\%) & $\begin{array}{l}\text { Flavonoids (mg/100 g dry wt) } \\
(\%)\end{array}$ & DPPH (\%) \\
\hline Control & 42.74 & 12.75 & 32.55 & 34.49 \\
\hline \multicolumn{5}{|l|}{$0 \mathrm{mg} / \mathrm{L}$ saline water } \\
\hline 20 mg/L chitosan & 43.25 & 38.54 & 34.94 & 42.97 \\
\hline 40 mg/L chitosan & 43.77 & 52.72 & 36.92 & 52.70 \\
\hline $20 \mathrm{mg} / \mathrm{L} \mathrm{CaCO}_{3}$ & 43.25 & 37.75 & 35.95 & 41.51 \\
\hline $40 \mathrm{mg} / \mathrm{L} \mathrm{CaCO}_{3}$ & 43.51 & 49.20 & 35.54 & 47.30 \\
\hline 5000 mg/l saline water & 41.72 & 12.14 & 39.95 & 42.74 \\
\hline \multicolumn{5}{|l|}{5000 mg/L saline water } \\
\hline 20 mg/L chitosan & 41.97 & 42.87 & 42.23 & 54.55 \\
\hline 40 mg/L chitosan & 42.74 & 60.52 & 43.94 & 61.85 \\
\hline $20 \mathrm{mg} / \mathrm{L} \mathrm{CaCO}_{3}$ & 41.72 & 40.56 & 43.59 & 50.60 \\
\hline $40 \mathrm{mg} / \mathrm{L} \mathrm{CaCO}_{3}$ & 41.79 & 56.64 & 43.21 & 59.01 \\
\hline LSD (5\%) & 0.28 & 0.42 & 1.20 & 0.43 \\
\hline
\end{tabular}


concentrations of chitosan enhanced bean and pea growth and yield through increasing plant immunity to different kinds of stress. Chitosan is considered as one of growth regulators and as a signal molecules in addition to its role as a high effective biomolecule (Górnik et al. 2008). Moreover, this promotive role resulted by enhancing activities of enzymes of nitrogen metabolism as well as improving the translocation of nitrogen in the leaves thus increased growth and development (Sultana et al. 2017). Chitosan treatment induces overexpression of genes involved in photosynthesis, changes in programming of protein metabolism with an enhancement of various storage proteins and hormone metabolism (Landi et al. 2017).

Similar findings were reported earlier concurrent with our obtained positive results of $\mathrm{Ca}^{+}$on different plant under abiotic stresses as Shoresh et al. (2011), Zehra et al. (2012), Xu et al. (2013), Ibrahim et al. (2016) and Haleema et al. (2018) and Sadak et al. (2020). The positive role of $\mathrm{Ca}^{2+}$ might be attributed to that $\mathrm{Ca}^{2+}$ was suggested to be a crucial secondary messenger that used in signaling-related processes to many defense mechanisms which are induced by salinity stress (Tuteja 2009). $\mathrm{Ca}^{2+}$ can increase membrane stability and protect them from lipid peroxidation and oxidative stress induced by salinity stress, thus improving water status of plant (Nayek et al. 1983 and Shao et al. 2008) as calcium is an important constituent of plant cell wall and plays an important role in cell division and enlargement.

It is obvious that irrigation of wheat plants with saline water significantly decreased photosynthetic pigments in addition to chlorophyll- $a$ /chlorophyll- $b$ ratio and endogenous indole acetic acid contents in the plant leaves (Table 4). These reductions in different photosynthetic pigments components in response to salt stress were confirmed on various plants Sakhonwasee and Phingkasan (2017) on tomato plant. These decreases might be referred to the increased levels of reactive oxygen species (ROS) production and oxidative stress that happened with salinity stress, thus damaging chloroplast membranes and the antagonistic effects of sodium ion on magnesium ion absorption (Smirnoff 1993). As well as, these decreases could be considered as an important regulatory step to avoid the absorbance of high light and the over reduction of photosynthetic electron transport chain, thus increasing the production of ROS (MunneBosch and Alegre 2000; Mazars et al. 2010).

The obtained results showed that chitosan treatment increased photosynthetic pigments. These increases could be due to improving cytokinins contents that stimulated chlorophylls synthesis or to the increased availability of amino compounds released from chitosan (Chibu and Shibayama 2001). Farouk and Amany (2012) stated that chlorophylls and carbohydrates of cowpea plant were reduced under water stress, whereas foliar application of chitosan significantly increased these parameters. Moreover, Khan et al. (2002) who reported that chitosan significantly increased photosynthetic pigments in maize and soybean plants. Pereira et al. (2017) found that chitosan treatment increased photosynthetic pigments of Phaseolus vulgaris. In another report, Behboudi et al. (2018) foliar treatment of chitosan increased photosynthetic pigments of barley plant. These results might be due to the increases of nitrogen and magnesium contents in the leaves because nitrogen and magnesium are the most important elements in the chemical composition of chlorophylls (Dzung et al. (2011).

The enhancement of photosynthetic pigment obtained in wheat leaves by foliar treatments of $\mathrm{CaCO}_{3}$ had been proved previously on different species as pepper (Yang et al. 2016) and tung tree (Li et al. 2017). This promotive effect might be attributed to the effect of $\mathrm{Ca}^{2+}$ in preventing dehydration damage of cellular structures via maintaining the osmotic strength of cytoplasm in plants (Arshi et al. 2006).

Salinity stress decreased significantly IAA contents of wheat leaves (Table 4). In agreement with the obtained results, Khater et al. (2018) stated that subjecting cowpea plant to stress decreased IAA contents. Generally, the reduction of different phytohormones among them IAA caused by different abiotic stresses might be attributed the decrease in enzyme activity which participates in phytohormone synthesis and/or increases in enzymes participate in its degradation (Vaseva-Gemisheva et al. 2005). Moreover, different treatments could increase IAA contents of wheat plants. Muthukrishnan et al. (2019) confirmed the promoting role of chitosan on IAA contents of chickpea plant. These increases might be due to the induced effect of Chito on auxin-related gene expression, accelerated IAA biosynthesis and transport and reduced IAA oxidase activity increases (Li et al. 2019).

Data presented in Table 5 indicated that irrigation of wheat plants with saline water significantly increased total soluble sugars (TSS), proline content and phenolics. Moreover, treating wheat plants either with chitosan or calcium carbonate resulted in obvious significant increases in the above-mentioned parameters. The obtained results on proline and TSS of wheat plants are confirmed in various plant species under stress $\mathrm{Ku}$ et al. (2012) on Nicotiana benthamiana plant, El-Bassiouny and Sadak (2015) on flax plant, Ibrahim et al. (2016) on sunflower plant. These increases in the two major organic osmolytes contents (proline and TSS) might help plants to regulate osmotic potential of cells which led to improve water absorbance and translocation under salinity stress (Oraki et al. 2012). As well as, proline is 
involved in protection of cellular structures, different enzymes from oxidative damages and acts as scavenger of free radical (Rady et al. 2015). With respect to phenol contents, phenolic compounds are antioxidants which trigger a series of secondary metabolites formed via shikimic acid or malonic acid cycles, as well as it has a cellular signaling functions (Michalak 2006).

It is well known that free radical-induced peroxidation of membrane lipids is an indicator of damage induced by stress at the cellular level (Jain et al. 2001). Thus, MDA level produced during lipids membrane peroxidation is usually used as an indicator of oxidative damage. Guimaraes et al. (2011) showed that increased MDA content might result in electrolyte leakage, indicating a loss of membrane integrity. As well as, salinity stress increased effect on MDA and $\mathrm{H}_{2} \mathrm{O}_{2}$ contents could be attributed to the inadequate induction of antioxidant system (Hossain et al. 2013). The $\mathrm{H}_{2} \mathrm{O}_{2}$ may play a role as a secondary messenger in response to abiotic stress, leading to a tolerance increase toward these unfavorable conditions, by maintaining cellular homeostasis through the antioxidant enzymes SOD, POX and CAT. The role of Chitosan on decreasing MDA and $\mathrm{H}_{2} \mathrm{O}_{2}$ contents might be proposed that $\mathrm{CHT}$ receptors are present on the plasma membrane; however, through a signaling cascade, the chloroplast is the primary CHT action organelle (Hadwiger 2013). Charge-charge interactions between positively charged CHT amine groups and negatively charged phospholipids promote a signal that will lead to the octadecanoid pathway activation; this metabolic pathway is directly related to the decreased $\mathrm{H}_{2} \mathrm{O}_{2}$ formation (Pichyangkura and Chadchawan 2015; Almeida et al. 2020).

Meanwhile, 20 and $40 \mathrm{mg} / \mathrm{L} \mathrm{CaCO}_{3}$ decreased MDA contents. These results are similar to those obtained by Issam et al. 2012, Xu et al. (2013) and Kaur et al. (2017) on different plant species. Hydrogen peroxide is used in different biochemical processes and signaling cascades required for plant growth and development. Generally, $\mathrm{H}_{2} \mathrm{O}_{2}$ contents increased in various plants subjected to stress (Dawood et al. 2014; Sadak, 2016; Kaur et al. 2017). In our investigation, $\mathrm{H}_{2} \mathrm{O}_{2}$ content increased in wheat plant subjected to salinity stress, whereas calcium chloride treatment decreased $\mathrm{H}_{2} \mathrm{O}_{2}$ contents. These obtained results are in harmony with those obtained by Amor et al. (2010) and Sadak et al. (2020).

Regarding to antioxidant enzymes, Table 6 clearly showed that irrigation of wheat plants with $5000 \mathrm{mg} / \mathrm{L}$ saline water caused significant increases in different enzymes superoxide dismutase SOD, peroxidase POX and catalase CAT as compared to those plants irrigated with tap water. Treatment of wheat grains with chitosan or $\mathrm{CaCO}_{3}$ significantly promoted the activity of various antioxidant enzymes (SOD and POX) as compared to the control (Table 6). On the other hand, CAT activity was significantly decreased as a result of chitosan or $\mathrm{CaCO}_{3}$ treatments. The highest CAT activity $(\mathrm{U} / \mathrm{min} / \mathrm{g} \mathrm{FW})$ was recorded in plants irrigated with $5000 \mathrm{mg} / \mathrm{l}$ saline water followed by control plants which recoded 36.40 and $24.82 \mathrm{U} / \mathrm{min} / \mathrm{g}$ FW, respectively. Plants normally cope with oxidative damage by increasing the activity of antioxidant enzymes in which it indicates stress resistance in plants (Weng et al. 2015). The enhancing effect of salinity stress is confirmed earlier on different plant species Ibrahim et al. (2016) on sunflower and Kaur et al. (2017). Oxidative stress is an important sign of abiotic stress and the increased SOD, POX and CAT activities were correlated with increasing protection from destructive resulted from oxidative stress (Miller et al. 2010). Superoxide is converted by the SOD enzyme into $\mathrm{H}_{2} \mathrm{O}_{2}$ which is still toxic and must be removed via transformation to $\mathrm{H}_{2} \mathrm{O}$ in the next step. $\mathrm{H}_{2} \mathrm{O}_{2}$ is then eliminated by conversion to $\mathrm{H}_{2} \mathrm{O}$ by POX enzyme (Parida et al. 2004). Peroxidases are important enzymes in various biochemical processes in plant, either in response to biotic or abiotic stresses. Also in the scavenging of ROS and plant cells protection from $\mathrm{H}_{2} \mathrm{O}_{2}$ injury (Bowler et al. 1992). The present study demonstrated that chitosan pretreatment induces the activities of SOD, POX and CAT. It was also reported that chitosan alleviates the adverse effect of water stress by enhanced production of antioxidant enzymes (Hidangmayum et al. 2019). The result also corresponded to the previous studies, which also revealed that chitosan application increases SOD, POX and CAT activities in wheat under salinity stress in wheat and maize seedlings under salt stress condition (Peykani and Sepehr 2018).

Generally, the effect of calcium carbonate on antioxidant enzymes of plant under salinity stress is in accordance with Amor et al. (2010), Xu et al. (2013) and Ibrahim et al. (2016). Eventually, the above-mentioned relationship confirmed that $\mathrm{CaCl}_{2}$ has an important role in alleviation water stress in wheat plant by adjusting membrane integrity, cell wall structure and improving water status of plant or by its direct role on osmolytes and antioxidants. As well as, $\mathrm{Ca}$ is involved in the biosynthesis of cell wall and interacts with phytohormones (Barker and Pilbeam 2007). Therefore, calcium acts as a site-specific cofactor on peroxidase enzyme (Mac-laughein and Wimmer 1999).

Data presented in Table 7 indicated that irrigation of wheat plants with saline water significantly decreased carbohydrate \% and protein \% compared with the control plants. Meanwhile, increased significantly flavonoids content and DPPH activities of the yielded grains of wheat plant as compared with control plants. Treating wheat plants either with chitosan or calcium carbonate with different concentrations resulted in obvious 
significant increases in carbohydrates, protein content, flavonoids contents and DPPH activities especially in plants treated with $40 \mathrm{mg} / \mathrm{L}$ chitosan followed by $40 \mathrm{mg} / \mathrm{L}$ calcium carbonate (Table 7). These decreases on carbohydrates contents are mainly due to the reduction in growth parameters (Table 2) and photosynthetic pigments (Table 4). Carbohydrate and protein changes of the yielded grains are of particular importance because of their direct relationship with such physiological processes as photosynthesis, translocation and respiration (Dubey and Pessarakli 2001). Salinity stress decreased chlorophyll contents in leaves, thus causing reduction of photosynthetic activity. So, decreased carbohydrates accumulation in mature leaves might reduce carbohydrate transport from leaves to the developing grains (Neslihan-Ozturk et al. 2002; Liu et al. 2004). On the other hand, the stimulating effect of chitosan and $\mathrm{Ca}^{+}$ treatments on carbohydrate contents of yielded grains might be due to the increases in growth parameters and photosynthetic pigments (Table 3). As well as, these increases in carbohydrate and proteins contents might be due to the increased photosynthetic output so decreased carbohydrates formation in leaves increased the translocation of carbohydrate from leaves to developing grains.

Flavonoids are plant secondary metabolites, the antioxidant activity (DPPH) of which depends on the presence of free $\mathrm{OH}$ groups, especially $3-\mathrm{OH}$. Plant flavonoids have antioxidant activity in vitro and also act as antioxidants in vivo (Geetha et al. 2003). As this is the first report on the antioxidant activity of grains of wheat thorough phytochemical analyses should be done to identify the active phenolic and flavonoid components. The increased contents of flavonoid under saline conditions may reflect some kind of defense against stress conditions (i.e., oxidative burden) since salt stress was accompanied by increased production of reactive oxygen species (Rezazadeh et al. 2012). Exogenous treatment of wheat plants with chitosan or $\mathrm{CaCO}_{3}$ resulted in a significant increase in flavonoids contents compared to untreated plants. These observations reveal that the bioactive molecule of treatments may be an inducer for the biosynthesis of secondary metabolites (flavonoids) which act as oxygen scavengers to reduce oxidative stress and, hence, increase the growth and yield wheat plant (Table 7).

Data in Table 7 showed that salinity stress caused significant increases the antioxidant activity (as DPPHradical scavenging capacity) of wheat grain. Also, foliar treatment of wheat plant with chitosan and $\mathrm{CaCO}_{3}$ with different concentrations (20 and $40 \mathrm{mMl}$ ) caused significant increases in the antioxidant activity as compared with control plants. Yu et al. (2002) suggested that significant levels of antioxidant activities and phenolic components have been detected in wheat and wheatbased food products and indicated that wheat may serve as an excellent dietary source of natural antioxidants for disease prevention and health promotion. The increase in the scavenging activity can be considered an advantage of treatment used. This could be attributed to the increases in total phenols and total flavonoids (Abd Allah et al. 2020; Orabi et al. 2015).

\section{Conclusion}

From the obtained data, it could be concluded that salinity stress adversely affected growth and biochemical parameters as compared with control plants. Meanwhile, soaking wheat grains in chitosan or calcium carbonate before sowing, especially in the higher dose (i.e., $40 \mathrm{mg} / \mathrm{L}$ ) have a significant positive effect on plant growth, photosynthetic pigments, yield, yield components and bio-yield. It is obvious that application of chitosan or $\mathrm{CaCO}_{3}$ significantly increased growth, yield quantity and quality via increasing photosynthetic pigments, indole acetic acid, total soluble sugars, proline, phenolics and the activity of some antioxidant enzymes. Moreover, wheat plants treated with chitosan or $\mathrm{CaCO}_{3}$ gave higher technological characteristics of grain like carbohydrate\%, protein \%, flavonoids and antioxidant activities.

\section{Abbreviations \\ $\mathrm{Ca}^{+}$: Calcium; $\mathrm{CaCO}_{3}$ : Calcium carbonate; Chlo-a: Chlorophyll a; Chlo-b: Chlo- rophyll $b$; IAA: Indole acetic acid; TSS: Total soluble sugars; MDA: Malondialde- hyde; $\mathrm{H}_{2} \mathrm{O}_{2}$ : Hydrogen peroxide; SOD: Superoxide dismutase; POX: Peroxidase; CAT: Catalase; DPPH: 2,2-Diphenyl-1-picryl-hydrazyl-hydrate assay.}

\section{Authors' contributions}

MShS designed and performed the experiment, responsible of all the physiological and biochemical analysis and also wrote and reviewed the manuscript. IMT designed and performed the experiment, statistical analysis, responsible of all the physiological and biochemical analysis and also wrote and reviewed the manuscript. All authors read and approved the final manuscript.

\section{Funding}

There are currently no funding sources in the design of the study and collection, analysis and interpretation of data, and in writing of the manuscript.

Availability of data and materials

The datasets generated and/or analyzed during the current study are included in this published manuscript.

\section{Declarations}

Ethics approval and consent to participate Not applicable.

Consent for publication

Not applicable.

Competing interests

The authors declare that they have no competing interests. 
Received: 19 June 2021 Accepted: 18 July 2021

Published online: 27 July 2021

\section{References}

Abdallah MMS, Ramadan AE, El-Bassiouny HMS, Bakry BA (2020) Regulation of antioxidant system in wheat cultivars by using chitosan or salicylic acid to improve growth and yield under salinity stress. Asian J Plant SC 19(2):114-126

Abdel-Mawgoud AMR, Tantawy AS, El-Nemr MA, Sassine TN (2010) Growth and yield response of strawberry plants to chitosan application. Eur J Sci Res 39:170-177

Achary VMM, Parinandi NL, Panda BB (2013) Calcium channel blockers protect against aluminium-induced DNA damage and block adaptive response to genotoxic stress in plant cells. Toxicol Environ Mutagen 751:130-138

Almeida LG, Magalhães PC et al (2020) Chitosan application in the induction of water deficit tolerance in maize plants. Acta Sci Agron 42:e42463. https://doi.org/10.4025/actasciagron.v42i1.42463

Amor NB, Megdiche W, Jimenez A, Sevilla F, Abdelly C (2010) The effect of calcium on the antioxidant systems in the halophyte Cakile maritima under salt stress. Acta Physiol Plants 32:453-461. https://doi.org/10. 1007/s11738-009-0420-2

Anjum F, Yaseen M, Rasul E, Wahid A, Anjum S (2003) Water stress in barley. I. Effect on chemical composition and chlorophyll content. Pak J Agric Sci 40:45-49

AOAC (1990) Official methods of analysis, 20th edn. Association of Official Analytical Chemists, Arlington, Virginia, USA (No 984.13)

Arshi A, Abdin MZ, lqbal M (2006) Effect of $\mathrm{CaCl} 2$ on growth performance, photosynthetic efficiency and nitrogen as simulation of Cichorium intybus L. grown under $\mathrm{NaCl}$ stress. Acta Physiol Plant 28:137-147

Ashraf M (2004) Some important physiological selection criteria for salt tolerance in plants flora - morphology distribution functional. Ecol Plants 199(5):361-376. https://doi.org/10.1078/0367-2530-00165

Ashraf M, Shahbaz M, Ali Q (2013) Drought-induced modulation in growth and mineral nutrients in canola (Brassica napus L.). Pak J Bot 45:93-98

Bakhoum GS, Sadak MS, Badr EA (2020) Mitigation of adverse effects of salinity stress on sunflower plant (Helianthus annuus L.) by exogenous application of chitosan. Bull Natl Res Centre 44:79. https://doi.org/10.1186/ s42269-020-00343-7

Barker AV, Pilbeam DJ (2007) Handbook of plant nutrition. Taylor and Francis Group, New York, pp 121-144

Bates LS, Waldan RP, Teare LD (1973) Rapid determination of free proline under water stress studies. Plant Soil 39:205-207

Behboudi F, TahmasebiSarvestani Z, ZamanKassaee M, ModaresSanavi SAM, Sorooshzadeh A, Ahmadi SB (2018) Evaluation of chitosan nanoparticles effects on yield and yield components of barley (Hordeum vulgare L.) under late season drought stress. J Water Environ Nanotechnol 3(1):22-39. https://doi.org/10.22090/jwent.2018.01.003

Bergmeyer HU (1974) Methods of enzymatic analysis, 2nd edn. Academic Press, New York

Bittelli M, Flury M, Campbell GS, Nichols EJ (2001) Reduction of transpiration through foliar application of chitosan. Agric Forest Meteorol 107:167-175

Boonlertnirum S, Meechoul S, Sarobol E (2010) Physiological and morphological responses of field corn seedlings to chitosan under hypoxic conditions. Sci Asia 36:89-93

Bouschet T, Martin S, Henley JM (2008) Regulation of calcium-sensing-receptor trafficking and cell-surface expression by GPCRs and RAMPs. Trends Pharmacol Sci 29:633-639

Bowler C, Van Montagu M, Inze D (1992) Superoxide dismutase and stress tolerance. Annu Rev Plant Physiol Plant Mol Biol 43:83-116

Chang C, Yang M, Wen H, Chern J (2002) Estimation of total flavonoid content in propolis by two complementary colorimetric methods. J Food Drug Anal 10(2002):178-182

Chen JX, Wang XF (2006) Plant physiology experimental guide. Higher Education Press, Beijing, pp 24-25

Chibu H, Shibayama H (2001) Effects of chitosan applications on the growth of several crops. In: Uragami T, Kurita K, Fukamizo T (eds) Chitin and chitosan in life science
Chookhongkha YN, Miyagawa S, Jirakiattikul Y, Photchanachai S (2012) Chili growth and seed productivity as affected by chitosan. In: Proceedings of the international conference on agriculture technology and food sciences, Manila, Philippines

ChunYan L, GuoRui M, WenYing H (2003) Induction effect of chitosan on suppression of tomato early blight and its physiological mechanism. J Zhejiang Univ Agric Life Sci 29:280-286

Cousson A (2009) Involvement of phospholipase C-independent calciummediated abscisic acid signaling during Arabidopsis response to drought. Biol Planta 53:53-62

Danil AD, George CM (1972) Peach seed dormancy in relation to endogenous inhibitors and applied growth substances. J Am Soc Hort Sci 17:621-624

Dawood MG, Sadak MS (2014) Physiological role of glycinebetaine in alleviating the deleterious effects of drought stress on canola plants (Brassica napus L.). Middle East J Agric Res 3(3):943-954

Devlieghere F, Vermeulen A, Debevere J (2004) Chitosan: antimicrobial activity, interactions with food components and applicability as a coating on fruit and vegetables. Food Microb 27:703-714

Dubey RS, Pessarakli M (2001) Physiological mechanisms of nitrogen absorption and assimilation. In plants under stressful conditions. In: Passarakli M (ed) Handbook of plant and crop physiology, 2nd edn, Marcel Dekker Inc., New York, pp 636-655

Dzung NA, Phuong VT, Dzung TT (2011) Research on impact of chitosan oligomers on biophysical characteristics, growth, development and drought resistance of coffee. Carbohydr Polym 84:751-755

El-Bassiouny HM, Sh M, Sadak, (2015) Impact of foliar application of ascorbic acid and a-tocopherol on antioxidant activity of flax cultivars under salinity stress. Acta Biol Colomb 20(2):209-222

Farouk S, Amany AR (2012) Improving growth and yield of cowpea by foliar application of chitosan under water stress. Egypt J Biol 14(1):14-16

Farouk S, Ghoneem KM, Ali Abeer A (2008) Induction and expression of systematic resistance to downy mildew disease in cucumber plant by elicitors. Egypt J Phytopath 1-2:95-111

Farouk S, Mosa AA, Taha AA, Heba MI, ELGahmery AM (2011) Protective effect of humic acid and chitosan on radish (Raphanus sativus L. var. sativus) plants subjected to cadmium stress. J Stress Physiol Biochem 7:99-116

Geetha M, Sai-Ram SS, Mongia V, Singh G-G et al (2003) Evaluation of antioxidant activity of leaf extract of sea buckthorn (Hippophae rhamnoides L.) on chromium ( $\mathrm{VI}$ ) induced oxidative stress in albino rats. J Ethnopharmacol 87:247-251

Ghoname AA, El-Nemr MA, Abdel-Mawgoud AMR, El-Tohamy WA (2010) Enhancement of sweet pepper crop growth and production by application of biological, organic and nutritional solutions. Res J Agric Bio Sci 6:349-355

Gornik K, Grzesik M, Duda BR (2008) The effect of chitosan on rooting of grapevine cuttings and on subsequent plant growth under drought and temperature stress. J Fruit Ornament Plant Res 16:333-343

Guimarães FVA, de Lacerda CF, Marques EC, de Miranda MRA, de Abreu CEB et al (2011) Calcium can moderate changes on membrane structure and lipid composition in cowpea plants under salt stress. Plant Growth Regul 65:55-63. https://doi.org/10.1007/s10725-011-9574-1

Gyamfi MA, Yonamine M, Aniya Y (2002) Free radical scavenging action of medicinal herbs from Ghana Thonningia sanguine on experimentally induced liver injuries. Gen Pharmacol 2002(32):661-667

Hadwiger LA (2013) Multiple effects of chitosan on plant systems: solid science or hype. Plant Sci 208:42-49. https://doi.org/10.1016/J.PLANTSCI. 2013.03.007

Hadwiger LA, Klosterman SJ, Choi JJ (2002) The mode of action of chitosan and its oligomers in inducing plant promoters and developing disease resistance in plants. In: Suchiva K, Chandrkrachang S, Methacanon P Peter MG (eds) Advances in chitin science, vol 5, Bangkok, pp 452-457. ISBN 974-229-412-7

Haleema B, Rab A, Hussain SA (2018) Effect of calcium, boron and zinc Foliar application on growth and fruit production of tomato. Sarhad J Agric 34(1):19-30

Herbert DP, Phipps J, Strange RE (1971) Chemical analysis of microbial cells. Methods Microbiol 5:209-344. https://doi.org/10.1016/S0580-9517(08) 70641-X

Hidangmayum A, Dwivedi P, Katiyar D, Hemantaranjan A (2019) Application of chitosan on plant responses with special reference to abiotic 
stress. Physiol Mol Biol Plants 25:313-326. https://doi.org/10.1007/ s12298-018-0633-1

Hodges DM, De Long JM, Forney C, Prange PK (1999) Improving the thiobarbituric acid reactive substances assay for estimating lipid peroxidation in plant tissues containing anthocyanin and other interfering compounds. Planta 207:604-611

Homme PM, Gonzalez B, Billard J (1992) Carbohydrate content, frutane and sucrose enzyme activities in roots, stubble and leaves of rye grass (Lolium perenne L.) as affected by sources/link modification after cutting. J Plant Physiol 140:282-291

Hossain MA, Mostofa MG, Fujita M (2013) Cross protection by cold-shock to salinity and drought stress-induced oxidative stress in mustard (Brassica campestris L.) seedlings. Mol Plant Breed 4:50-70

Ibrahim MFM, Faisal A, Shehata SA (2016) Calcium chloride alleviates water stress in sunflower plants through modifying some physio-biochemical parameters. Am Euras J Agric Environ Sci 16(4):677-693

Issam N, Kawther M, Haythem M, Moez J (2012) Effects of $\mathrm{CaCl}_{2}$ pretreatment on antioxidant enzyme and leaf lipid content of faba bean (Vicia faba L.) seedlings under cadmium stress. Plant Growth Regul 68:37-47. https:// doi.org/10.1007/s10725-012-9691-5

Jain M, Mathur G, Koul S, Sarin NB (2001) Ameliorative effects of proline on salt stress-induced lipid peroxidation in cell lines of groundnut (Arachis hypogaea L.). Plant Cell Rep 20:463-468

Kaur H, Bhardwaj RD, Grewal SK (2017) Mitigation of salinity-induced oxidative damage in wheat (Triticum aestivum L.) seedlings by exogenous application of phenolic acids. Acta Physiol Plant 39:221

Khan WM, Brithiviraj B, Smith DL (2002) Effect of foliar application of chitin and chitosan oligosaccharides on photosynthesis of maize and soybean. Photosynthetica 40:621-624

Khan R, Manzoor N, Zia A, Ahmad I, Ullah A, Shah SM, Naeem M, Ali S, Khan IH, Zia D, Malik S (2018) Exogenous application of chitosan and humic acid effects on plant growth and yield of pea (Pisum sativum). Inter J Biosci 12(5):43-50

Khater MA, Dawood MG, Sadak MS, Shalaby MAF, El-Awadi ME, El-Din KG (2018) Enhancement the performance of cowpea plants grown under drought conditions via trehalose application. Middle East J Agric Res 7(3):782-800

Kong FX, Hu W, Chao WL, Sang WL, Wang LS (1999) Physiological responses of Mexicana to oxidative stress of SO2. Environ Exp Bot 42:201-209

Ku HM, Tan CW, Su YS, Chiu CY, Chen CT, Jan FJ (2012) The effect of water deficit and excess copper on proline metabolism in Nicotiana benthamiana. Biol Plant 56:337-343

Landi L, De Miccolis Angelini RM, Pollastro S, Feliziani E, Faretra F, Romanazzi G (2017) Global transcriptome analysis and identification of differentially expressed genes in strawberry after preharvest application of Benzothiadiazole and chitosan. Front Plant Sci 2017(8):235

Larsen P, Harbo A, Klungron S, Ashein TA (1962) On the biosynthesis of some indole compounds in Acetobacter Xylinum. Physiol Plant 15:552-565

Li Z, Tan XF, Lu K, Liu ZM, UI L (2017) The effect of $\mathrm{CaCl}_{2}$ on calcium content, photosynthesis, and chlorophyll fluorescence of tung tree seedlings under drought conditions. Photosynthetica 55(3):553-560

Li R, He J, Xie H, Wang W, Bose SK, Sun Y, Hu J, Yin H (2019) Effects of chitosan nanoparticles on seed germination and seedling growth of wheat (Triticum aestivum L.). Int J Biol Macromol 126:91-100

Lichtenthaler HK, Buschmann C (2001) Chlorophylls and carotenoids: measurement and characterization by UV-VIS spectroscopy. In: Wrolstad RE, Acree TE, An H, Decker EA, Penner MH, Reid DS, Schwartz SJ, Shoemaker CF, Sporns P (eds) Current protocols in food analytical chemistry (CPFA). Wiley, New York, pp F4.3.1-F4.3.8

Liu F, Jensen CR, Andersen MN (2004) Drought stress effect on carbohydrate concentration in soybean leaves and pods during early reproductive development: Its implication in altering pod set. Field Crops Res $86: 1-13$

Mac-laughein SB, R. wimmer, (1999) Calcium physiology and terrestrial ecosystem processes, tansley Review n. 104. New Physiol 142:373-417

Mazars C, Thuleaua P, Lamotte O, Bourque S (2010) Cross-talk between ROS and calcium in regulation of nuclear activities. Mol Plant 3(4):706-718

Michalak A (2006) Phenolic compounds and their antioxidant activity in plants growing under heavy metal stress. Plant Cell 15:523-530
Miller G, Suzuki N, Ciftci-yilmaz S, Mittler R (2010) Reactive oxygen species homeostasis and signalling during drought and salinity stresses. Plant Cell Environ 33:453-467

Misra N, Dwivedi UN (2004) Genotypic difference in salinity tolerance of green gram cultivars. Plant Sci 166(5):1135-1142

Mondal M, Malek M, Puteh A, Ismail M (2013) Foliar application of chitosan on growth and yield attributes of mungbean (Vignaradiata (L.) Wilczek). Bangladesh J Bot 42:179-183

Munné-Bosch S, Alegre L (2000) The xanthophyll cycle is induced by light irrespective of water status in field-grown lavender (Lavandula stoechas) plants. Physiol Plant 108:147-151

Muthukrishnan S, Murugan I, Selvaraj M (2019) Chitosan nanoparticles loaded with thiamine stimulate growth and enhances protection against wilt disease in Chickpea. Carbohyd Polym. https://doi.org/10.1016/j.carbp ol.2019.02.037

Nayek B, Biswas AK, Choudhuri MA (1983) Effect of calcium on water-stressinduced biochemical changes and yield of field-grown rice. Biol Plant 25:117-123

Neslihan-Ozturk Z, Talam V, Deyholos M, Michalowski CB, Galbraith DM, Gozukirmizi N, Tuberosa R, Bohnert HJ (2002) Monitoring large-scale changes in transcript abundance in drought- and salt stressed barley. Plant Mol Biol 48:551-573

No HK, Lee KS, Kim ID, Park MJ, S.D. Kim and S.P. Meyers, (2003) Chitosan treatment affects yield, ascorbic acid content and hardness of soybean sprouts. J Food Sci 68:680-685

Orabi SA, Dawood MG, Salman SA (2015) Comparative study between the physiological role of hydrogen peroxide and salicylic acid in alleviating the harmful effect of low temperature on tomato plants grown under sand. Sci Agric 9:49-59

Oraki H, Khanjani FP, Aghaalikhna M (2012) Effect of water deficit stress on proline contents, soluble sugars, chlorophyll and grain yield of sunflower (Helianthus annuus L.) hybrids. Afr J Biotechnol 11:164-168

Pan Z, Zhao Y, Zheng Y, Liu J, Jiang X, Guo Y (2012) Ahigh-throughput method for screening Arabidopsis mutants with disordered abiotic stressinduced calcium signal. J Genet Genom 39:225-235

Parida AK, Das AB, Mohanty P (2004) Investigations on the antioxidative defence responses to $\mathrm{NaCl}$ stress in a mangrove, Bruguiera parviflora: differential regulations of isoforms of some antioxidative enzymes. Plant Growth Regul 42:213-226

Patkowska E, Pieta D, Pastucha H (2006) The effect of biochikol 020 pc on microorganisms' communities in the rhizosphere of Faba bean plants. Polish Chitin Soc Monog 11:171-178

Pereira AS, Silva PM, Olivera JL, Olivera HC, Fraceto LF (2017) Chitosan nanoparticles as carrier systems for the plant growth hormone gibbereillic acid. Collodis Surf B Bioenterfaces 150:141-152

Peykani LS, Sepehr MF (2018) Effect of chitosan on antioxidant enzyme activity, proline, and malondialdehyde content in Triticum aestivum L. and Zea may L. under salt stress condition. Iran J Plant Physiol 9:2661-2670

Pichyangkura R, Chadchawan S (2015) Biostimulant activity of chitosan in horticulture. Sci Hortic 196(30):49-65. https://doi.org/10.1016/j.scienta. 2015.09.031

Rady MM, Sadak MS, El-Lethy SR, Abd El-Hamid EM, Abdelhamid MT (2015) Exogenous a-tocopherol has a beneficial effect on Glycine max (L.) plants irrigated with diluted sea water. J Hortic Sci Biotechnol 90(2):195-202

Rezazadeh A, Ghasemnezhad A, Barani M, Telmadarrehe T (2012) Effect of salinity on phenolic composition and antioxidant activity of artichoke (Cynara scolymus L.) leaves. Res J Med Plant 6:245-252

Sadak MS (2016) Physiological role of signal molecules in improving plant tolerance under abiotic stress. Int J Chem Technol Res 9:46-60

Sadak MSh, El-Enany MAM, Bakry BA, Abdallah MMS, El-Bassiouny HMS (2020) Signal molecules improving growth, yield and biochemical aspects of wheat cultivars under water stress. Asian J Plant Sci 19:35-53. https:// doi.org/10.3923/ajps.2020.35.53

Sakhonwasee S, Phingkasan W (2017) Effects of the foliar application of calcium on photosynthesis, reactive oxygen species production, and changes in water relations in tomato seedlings under heat stress. Hortic Environ Biotechnol 58(2):119-126 
Shao H, Song W, Chu L (2008) Advances of calcium signals involved in plant anti-drought. CR Biol 331:587-596

Sheikha SA, Al-Malki FM (2011) Growth and chlorophyll responses of bean plants to chitosan applications. Eur I Sci Res 50:124-134

Shoresh M, Spivak M, Bernstein N (2011) Involvement of calcium mediated effects on ROS metabolism in the regulation of growth improvement under salinity. Free Radic Biol Med 51:1221-1234. https://doi.org/10. 1016/j.freeradbiomed.2011.03.036

Smirnoff N (1993) The role of active oxygen in the response of plants to water deficit and desiccation. New Phytol 125:27-58

Snedecor GW, Cochran WG (1980) Statistical methods, 7th edn. lowa State Univ. Press, lowa

Stroganov BP (1962) Physiological basis of salt tolerance of plants as affected by various types of salinity. Izadatel 'Stvo Akademii Nauk, USSR, pp 279

Sultana S, Islam M, Khatun MA, Hassain MdA, Huque R (2017) Effect of foliar application of oligo-chitosan on growth, yield and quality of tomato and eggplant. Asian J Agric Res 11(2):36-42. https://doi.org/10.3923/ ajar.2017.36.42

Tuteja N (2009) Integrated calcium signaling in plants. In: Baluška F, Mancuso S (eds) Signaling and communication in plants. Springer, Berlin, pp 29-49

Vaseva-Gemisheva I, Lee D, Karanov E (2005) Response of Pisum sativum cytokinin oxidase /dehydrogenase expression and specific activity to drought stress and herbicide treatments. Plant Growth Regul 46:199-208

Velikova V, Yordanov I, Edreva A (2000) Oxidative stress and some antioxidant systems in acid rain-treated bean plants: protective role of exogenous polyamines. Plant Sci 5:59-66
Weng M, Cui L, Liu F, Zhang M, Shan L, Yang S, Deng XP (2015) Effects of drought stress on antioxidant enzymes in seedlings of different wheat genotypes. Pak J Bot 47(1):49-56

White PJ, Broadley MR (2003) Calcium in plants. Ann Bot 92:487-511

Xu C, Li X, Zhang L (2013) The effect of calcium chloride on growth, photosynthesis, and antioxidant responses of Zoysia japonica under drought conditions. PLoS ONE 8(7):e68214. https://doi.org/10.1371/journal. pone.0068214

Yang BZ, Liu ZB, Zhou SD et al (2016) Exogenous Ca2+ alleviates waterlogging-caused damages to pepper. Photosynthetica 54:620-629

Yemm EW, Willis AJ (1954) The respiration of barley plants. IX. The metabolism of roots during assimilation of nitrogen. New Phytotol 55:229-234

Yu L, Haley S, Perret J, Harris M (2002) Antioxidant properties of hard winter wheat extracts. Food Chem 78:457-461

Zehra A, Gul B, Ansari R, MA, Khan. (2012) Role of calcium in alleviating effect of salinity on germination of Phragmites karka seeds. S Afr J Bot 78:122-128

\section{Publisher's Note}

Springer Nature remains neutral with regard to jurisdictional claims in published maps and institutional affiliations.

\section{Submit your manuscript to a SpringerOpen ${ }^{\odot}$ journal and benefit from:}

- Convenient online submission

- Rigorous peer review

- Open access: articles freely available online

- High visibility within the field

- Retaining the copyright to your article

Submit your next manuscript at $\boldsymbol{\nabla}$ springeropen.com 